\title{
Invited author \\ Fundamental motor skill proficiency is necessary for children's motor activity inclusion
}

\author{
José Angelo Barela \\ São Paulo State University and Cruzeiro do Sul University, Brazil
}

\begin{abstract}
Motor development is influenced by many factors such as practice and appropriate instruction, provided by teachers, even in preschool and elementary school. The goal of this paper was to discuss the misconception that maturation underlies children's motor skill development and to show that physical education, even in early years of our school system, is critical to promote proficiency and enrolment of children's in later motor activities. Motor skill development, as a curricular focus, has been marginalized in many of our physical education proposal and in doing so, we have not promote motor competence in our children who lack proficiency to engage and to participate in later motor activities such as sport-related or recreational.
\end{abstract}

Keywords: motor development, skillfulness, fundamental motor skills, physical education

Resumo- “Proficiência nas habilidades motoras fundamentais é necessária para inclusão de crianças em atividades motoras." Desenvolvimento motor é influenciado por muitos fatores tais como prática e instrução apropriada, fornecidas por professores, até mesmo no ensino infantil e fundamental. O objetivo deste artigo foi discutir o entendimento errôneo de que maturação é o processo básico no desenvolvimento de habilidades motoras e mostrar que educação física, mesmo em anos iniciais do sistema escolar, é crucial para promover proficiência e, consequentemente, envolvimento de crianças em atividades motoras futuras. Desenvolvimento das habilidades motoras, como um foco do currículo escolar, tem sido marginalizado em muitas das nossas propostas de educação física e assim o fazendo, nós não temos promovido competência motoras em nossas crianças que não adquirem competência motora para engajar e participar de atividades motoras tais como as recreativas e esportivas.

Palavras-chaves: desenvolvimento motor, habilidoso, habilidades motoras fundamentais, educação física

Resumen- “Se requiere dominio de las destrezas básicas de movimiento para la inclusión de los niños en las actividades motoras." El desarrollo motor se ve influida por muchos factores, como la práctica y la instrucción apropiada, proporcionada por los maestros, incluso en el jardín infantil y primaria. El propósito de este artículo es analizar el malentendido de que el envejecimiento es el proceso básico en el desarrollo de las habilidades motoras y mostrar que la educación física, incluso en los primeros años del sistema escolar, es crucial para promover el dominio y por lo tanto la participación de niños en actividades motoras futuro. Desarrollo de las habilidades motoras, como un enfoque del plan de estudios, ha sido marginado en muchas de nuestras propuestas y la educación física hacerlo, hemos promovido la competencia motriz en nuestros niños que no adquieran competencia motriz para comprometerse y participar en las actividades motoras tales como actividades recreativas y deportivas.

Palabras claves: desarollo motor, habilidades motoras fundamentales, educación física

\section{Introduction}

No doubts that life is quite facilitated by many of the "modern" commodities that nowadays we literally have at hand. We can move from one place to other, around the world, not only quickly but also with much less efforts, at least compared to we use to a few decades ago. In addition, we can communicate to or contact to almost whomever we wish with just a few fingertip touches. Even in our near surroundings, we can turn on/off electronic devices with the "help" of our fingers. Actually, much of what we used to do by using whole body movements, nowadays, we just use the hands or even the fingers.

The conjunction of high rates of caloric ingestion and low level of physical activity leaded to a worldwide obesity epidemic. Overweight and obesity rates are dramatically scaling up, even in places that until recent years used to deal with lack of food. Half of Brazilians is overweighed and for one out of three Brazilian children between 5 to 9-yearold overweighting can be observed (IBGE, 2010). Such numbers have pushed several segments of our society to discuss and implement actions towards controlling the caloric ingestion and, less than one would expect, physical activities programs or promoting people's enrolment in activities aiming caloric consumption.

Promoting physical activity enrolment aiming health issue definitely is one of the main goals of physical activity program. We could discuss that this is not the only one, which argument I agree, but for the sack of our main focus of this contribution, I will only discuss physical activity 
enrolment toward health promotion. Specifically, I will address two main mistakes that in my opinion have influenced our understanding of the basic formation of motor repertory and how these mistakes have prevent or limited later involvement in physical activities and, consequently, prevent to use the health aspects of physical activity practice.

I will approach this issue by addressing that the formation of a motor repertory, basic requirement to get enrolled and involved in physical activities, is a result of a long process. That means to say that, similarly to other domains, a competent and confident practitioner (whichever level of chosen performance) requires a long period upon which these characteristics are gathered and mastered. As many have suggested, skill acquisition is characterized by sequential and ordered changes that take place throughout many years. More importantly, however, is that the process of skill acquisition is built upon previous experiences in such way that new acquisition or performance improvements depend on previous ones: skill acquisition is a cumulative process. Such characteristic implies that competence in motor skills is not only influenced by one whishes to perform well a task or a skill, but it is influenced by the experience that was built along many years.

\section{Motor acquisition (the first big mistake): Maturation}

During many years, explanation regarding motor acquisition was based upon the maturational viewpoint. In this case, fundamental motor skill acquisition was though to happen primarily due to maturation of central nervous, without much influence of the environment (Gesell, 1933; McGraw, 1949). This maturational misconception about skill acquisition pervaded many by long time since basic motor pattern do not need to be taught: infants and toddlers acquire walking, running, jumping, kicking and many others motor skills without the need of specific practice and instruction provided by a teacher or an instructor.

As Clark (2007) pointed out, for many, these skills seem to appear one day in child's collection of new behavior. Moreover, the appearance of these basic skills in one's life leaded parents and even educators to think that there is no need to teach them in early school years. Until the end of the first decade of life, motor skills do not require to be taught in a specific environment (for instance, at school), because skills such as walking, running, jumping, kicking, throwing, and many others simply appear! And because their appearance was thought to be due to maturation, they will appear at everyone's motor repertoire and at any environment circumstances. Specific practice and instruction would be required only at age that skill acquisition would not be primarily governed by maturation such as the specific sportrelated skills. Actually, my physical education experiences in the school system seem to resume exactly such idea: it started when I was 10-year-old, in the fifth grade (actual sixth year) of the school system.
The belief that maturation was the only driving factor of motor development in the early years is slowly fading away, although it is still a "ghost thought" that comes and goes more often that one (including myself) would expect to happen. Contemporary view of motor development assumes that motor skill development is quite complex, changing through an interactive process between the individual's biological constraints and the environment (Barela, 2007; Clark, 2007; Thelen, 2000). In this case, many biological systems (i.e., central nervous, sensory, muscles, skeleton, etc.) change with age and these changes are prescribed and governed by maturation and heredity, but our environment and our life experiences continuously modulate our biological heritage.

Early in life, our motor repertory has already many movements in place. For example, newborns have several reflexes, which are embedded in the nervous system and, therefore, are predetermined. However, the other motor behaviors of infancy, those so called species-typical or phylogenetic, are far less predetermined. Clark (1994) suggested that these behaviors are pre-adapted, which reflect a predisposition of the organism to perform certain actions, but require environmental support for their appearance (although minimal and nonspecific). Evolution has provided us with a genetic repertoire that makes it likely that behaviors necessary for survival will appear. However, if the environment demands change, we still have flexibility to change our developmental course.

Our interaction with the environment, however, demands not only that motor capabilities are in place at birth but also perceptual capabilities. Pre-adapted motor behaviors will be modified by infant's experience in the world through continuous cycles of action and perception. The constant dialogue between the newborn and its new stimulus-rich environment provides him/her with a rich and rapidly expanding collection of perceptual-motor experiences that help to shape his/her motor skills.

The innate motor patterns are a basis for the development of motor skills that appear later. Along with the innate perceptual capabilities, infants can modulate, adapt and learn new motor skill that will "appear" in their motor repertoire. Therefore, newborns and infants are motor and perceptual prepared to adapt to their new world, in such way that the innate motor and perceptual capabilities provide a basis that experience modifies and, over time, that they incorporate into and more complex patterns of coordination that are better suitable to the environmental requirements (Barela, 2007; Clark, 2007).

Perceptual and motor experiences, of course, do not only shape newborn and infant's motor repertoire early in life. We all experience similar adaptations to our perceptual-motor experiences, and these experiences guide us to shape our motor skills as they change throughout our life. However, such experiences definitely are more important in shaping our motor repertoire in specific periods of our developmental course, which seems also to be misunderstood by parents, instructors and teachers. 


\section{Motor acquisition (the second big mistake): Lack of proficiency}

Many theoretical motor development models (Clark, 1994; Gallahue, 1982; Gallahue \& Ozmun, 1989; Pellegrini \& Barela, 1998) suggest that the early motor development periods are critical to latter skill attainment. Yet, these theoretical models nominate one of these periods as fundamental motor skills or patterns, suggesting that this period is "fundamental," as providing a basis, for acquisition of new skills later in life. Despite of this understanding that it commonly accepted, we still struggle to properly emphasize and pay attention to fulfill the development of these fundamental motor skills.

Again, the maturation misconception that fundamental motor skills are acquired naturally, as they one day appear, seems also to pervade the idea that these skills are mastered by the children as they play and move around by themselves. Actually, most of the fundamental motor skills do not need to be taught, as they as acquired by children, as previously describe. Moreover, the performance also improves from the first attempts in performing these motor skills to the attempts that will be performed later in childhood. However, most of our children do not master these skills performance in a proficient level.

Proficiency has been suggested as an important aspect of motor skill development. Seefeldt (1980) argued that if fundamental motor patterns were not acquired, children would encounter difficulties, a "proficiency barrier," when trying to learn later motor skills that would lead to skillfulness. However, despite being important, during many years, it seems that Seefeldt's alert was neglected. Many might have been the reasons for little attention being paid for it, including that, again, children acquire these fundamental motor skill without specific requirements.

Gallahue and colleagues (Gallahue, 1982; Gallahue \& Donnelly, 2007) also pointed out that for many fundamental motor skills, performance of these skills would lack proficiency. In their theoretical contributions, these authors classified the performance of these skills by stages: initial; elementary, and mature. However, since his early work Gallahue (1982) emphasized that most of our children would not acquire the most proficient performance in the fundamental motor skills (the mature stage). For instance, recent studies have shown that Brazilian children are delayed in fundamental motor skill development (Braga, Krebs, Valentini, \& Tkac, 2009; Brauner \& Valentini, 2009), corroborating the suggestion that children might not attain the most proficient performance in these skills.

According to many of the motor development theoretical models (Clark, 1994; Gallahue, 1982; Gallahue \& Ozmun, 1989; Pellegrini \& Barela, 1998), fundamental motor skills should have already being mastered by seven-year-old children. What would prevent them to do so? As previously emphasized, most of our fundamental motor skills are naturally acquired, as the innate motor and perceptual capabilities provide a basis for the acquisition of these patterns. However, how these patterns will be changed over time, depends on adaptation and learning that will occur through perceptual-motor experiences that children would have during childhood.

Despite assuming a crucial aspect in promoting motor development, not all experiences will promote motor competence. Gallahue (1982) had suggested that fundamental motor skillfulness would require specific conditions of practice and recently suggested that proficiency in fundamental motor skills are influenced by opportunity and appropriate instruction and environment (Gallahue \& Donnelly, 2007). A few studies have demonstrated that specific intervention programs can promote improvement of fundamental motor skills (Braga et al., 2009; Brauner \& Valentini, 2009; Lopes, Lopes, \& Pereira, 2004). Additionally, we have recently showed that fundamental motor skill performance can be improved by regular physical education, provided by specialist teachers, in elementary school years (Cotrim, Lemos, Néri Jr., \& Barela, 2011) and even in the kindergarten (Lemos, Avigo, \& Barela, 2012). Based upon these results, we suggested that fundamental motor skill competence can be influenced by specific physical activity programs and by regular physical education, even early in life as such in kindergarten and elementary school years.

\section{Motor competence and a lifetime mover}

Although debatable, fundamental motor skills are considered as building blocks of later motor skill acquisition related to sport-specific movements and skillfulness (Clark, 2007). Moreover, if these motor skills are not mastered early in life, children may encounter difficulties when learning more complex motor skills and even not continue to pursue participation and to progress in motor activity towards skillfulness. Therefore, the results showing that enrollment in specific motor programs and, even more important, regular physical education can promote crucial improvement in fundamental motor skill performance are promising and we need to pay the necessary attention to physical education activities in early education.

We have recently investigated the effects of early physical education on fundamental motor skill development and on the enrollment in physical activity in kindergarten children (Rodrigues, Avigo, Leite, Bussolin, \& Barela, in press). Our results showed that those children who had regular physical education, provided by a specialist teacher, besides showing improved fundamental motor skill performance also maintain the same level of physical activity enrolment compared to children who only had physical activities from a non-specialized teacher. Although such enrolment did not show any change in somatic differences between children with different physical activities, the higher level of physical enrolment observed is an important and crucial factor that early programs of physical activity should target.

Finally, studies have shown positive effects of motor proficiency in early motor skills and enrolment in regular 
physical activities (Wrotniak, Epstein, Dorn, Jones, \& Rondilis, 2010) and even in sport activities at adolescence (Ridgway et al., 2009). Therefore, promotion of motor proficiency, even in fundamental motor skills, should be emphasized and becoming a specific goal, even in early ages. We should reject the misconception and the strong belief that in the first ten years of a child's life, motor skills "just develop." Fundamental motor skills might "just appear," but they do not refine by themselves. In order to master fundamental motor skills in proficient levels of performance, children need to practice and to receive appropriate instructions that would occur in preschool and elementary school. We definitely need to work and influence policy issues regarding the importance of preschool and elementary school in promoting motor skill development (Clark, 2007; Lemos et al., 2012).

Differently from what many may believe, promoting motor skill competence in preschool and elementary school years, children and adolescents would become capable of participating as a competent and motivate mover in later activities and many life long competent movers. In this way, inclusion is directed related to proficiency. Children who leave elementary school without a strong foundation in movement, those have not mastered the fundamental motor skill proficiency, are indeed "left behind:" these children, unfortunately nowadays the majority, are excluded by the peers in games and recreational activities. If not excluded by the peers, they aware of the lack of proficiency, selfexclude. They are not motivated to participate of the activities simply because they cannot perform and fulfill the motor requirements necessary to participate in that game or activity.

\section{References}

Barela, J.A. (2007). Adapted physical activity in promoting infant motor development. Sobama Journal, 12(1), 42 - 47.

Braga, R.K., Krebs, R.J., Valentini, N.C., \& Tkac, C.M. (2009). A influência de um programa de intervenção motora no desempenho das habilidades locomotoras de crianças com idade entre 6 e 7 anos. Revista da Educação Física/UEM, 20(2), 171-181.

Brauner, L.M., \& Valentini, N.C. (2009). Análise do desempenho motor de crianças participantes de um programa de atividades físicas. Revista da Educação Física/UEM, 20(2), 205-216.

Clark, J.E. (1994). Motor development. Encyclopedia of human behavior, 3, 245-255.

Clark, J.E. (2007). On the problem of motor skill development. JOPERD, 78(5), 39-45.

Cotrim, J.R., Lemos, A.G., Néri Jr., J.E., \& Barela, J.A. (2011). Desenvolvimento de habilidades motoras fundamentais em crianças com diferentes contextos escolares. Revista de Educação Física-UEM, 22(4), 523-533.

Gallahue, D.L. (1982). Understanding Motor Development in Children. Boston, MA: John Wiley \& Sons, Inc.

Gallahue, D.L., \& Donnelly, F.C. (2007). Developmental Physical Education for all Children (4th ed.). Urban-Champaign, IL: Human Kinetics.

Gallahue, D.L., \& Ozmun, J.C. (1989). Understanding Motor Development (3rd ed.). Madison, WI: Brown \& Benchmark Publishers.
Gesell, A. (1933). Maturing and the patterning of behavior. In C. Murchison (Ed.), A handbook of child psychology $\left(2^{\text {nd }} \mathrm{ed} ., \mathrm{pp}\right.$. 209-235). New York: Russell \& Russell.

IBGE. (2010). Antropometria e estado nutricional de crianças, adolescentes e adultos no Brasil. Retrieved 29/03/2013, 2013.

Lemos, A.G., Avigo, E.L., \& Barela, J.A. (2012). Physical Education in kindergarten promotes fundamental motor skill development. Advances in Physical Education, 2(1), 17-21.

Lopes, L., Lopes, V.P., \& Pereira, B. (2004). Atividade física no recreio escolar: Estudo de intervenção em crianças dos seis aos 12 anos. Revista Brasileira de Educação Física e Esporte, 20(4), 271-280.

McGraw, M.B. (1949). The neuromuscular maturation of the human infant. New York, NY: Hafner.

Pellegrini, A.M., \& Barela, J.A. (1998). O que o professor deve saber sobre o desenvolvimento motor de seus alunos. In M. C. D. O. Micotti (Ed.), Alfabetização: Assunto para pais e mestres (pp. 69-80). Rio Claro: Instituto de Biociências.

Ridgway, C. L., Ong, K.K., Tammelin, T.H., Sharp, S., Ekelund, U., \& Jarvelin, M.-R. (2009). Infant motor development predicts sports participation at age 14 years: Northern Finland birth cohort of 1966. PLoS One, 4(8), e6837.

Rodrigues, D., Avigo, E.L., Leite, M.M.V., Bussolin, R.A., \& Barela, J.A. (in press). Desenvolvimento motor e crescimento somático de crianças com diferentes contextos no ensino infantil. Motriz, 19(3).

Seefeldt, V. (1980). Developmental motor patterns: Implications for elementary school physical education. In C. H. Nadeau, W. R. Halliwell, K. M. Newell \& G. C. Roberts (Eds.), Psychology of Motor Behavior and Sport-1979 (pp. 314-323). Champaign, IL: Human Kinetics.

Thelen, E. (2000). Grounded in the world: developmental origins of the embodied mind. Infancy, 1(1), 3-28.

Wrotniak, B.H., Epstein, L.H., Dorn, Joan M., Jones, K., \& Rondilis, V.A. (2010). The relationship between motor proficiency and physical activity in children. Pedriatics, 118(6), e1758-e1765.

\section{Author's note}

José Angelo Barela is affiliated with the Laboratory of Movement Analysis, Institute of Physical Activity and Sport Sciences, Cruzeiro do Sul University, São Paulo, SP, Brasil and is also affiliated with the São Paulo State University, Rio Claro, State of São Paulo, Brazil.

\section{Correspondence}

Av. 24-A, 1515, Bela Vista, Rio Claro, SP 13506-900

Phone: (19) 35264340

E-mail: jbarela@rc.unesp.br

This study was presented as part of an invited lecture at the $8^{\text {th }}$ International Congress of Physical Education and Human Movement and $14^{\text {th }}$ Symposium Paulista Physical Education.

Declaration of Conflicting Interests: The authors declared no conflicts of interest with respect to the research, authorship, and/ or publication of this article.

Manuscript received on May 22, 2013

Manuscript accepted on May 26, 2013 